\title{
CHEMICAL CHANGES IN SEA WATER OFF PLYMOUTH DURING 1957
}

\author{
By F. A. J. Armstrong and E. I. Butler \\ The Plymouth Laboratory
}

(Text-figs. I-3)

Analyses of sea water collected during 1957 at the International Hydrographic Station E I (lat. $50^{\circ} \mathrm{O}^{\prime} \mathrm{N}$., long $4^{\circ} 22^{\prime} \mathrm{W}$.) are given here in the same form as in earlier reports (Armstrong, I954, I955, 1957, 1958). The methods of collection and of analysis for phosphorus and silicon are substantially unchanged. Some analyses were made for ammonia by a vacuum distillation method (Riley, I953), and for inorganic nitrogen (nitrate + nitrite + ammonia) by reduction of nitrate and nitrite with nickel (Riley \& Sinhaseni, I957) to ammonia, which was vacuum distilled. Salinities were determined by the Government Chemist's Department.

We wish to express our thanks to Lt.-Cdr. C. A. Hoodless and the crew of R.V. 'Sarsia' and to Capt. W. J. Creese and the crew of R.V. 'Sula', for assistance at sea.

\section{Temperature and salinity RESULTS}

The vertical distribution of temperature during the year is shown in Fig. I. The lowest surface temperature recorded was $9.7^{\circ} \mathrm{C}$. on 15 February, and the highest was $16 \cdot \mathrm{II}^{\circ} \mathrm{C}$. on $\mathrm{I} 6 \mathrm{July}$. Some vertical irregularities of temperature and salinity occurred in March and April, being most marked on 24 April, when water of salinity higher than on II April, higher than in the layers above, and marked by its lower silicate content, was present at 50 and $70 \mathrm{~cm}$. (Table 2). As is seen there was a temperature minimum at $20 \mathrm{~m}$, but the densities show the vertical stability.

A sharp thermocline between I 5 and 20 m was established by II June, and persisted with some change of level until September. From October until the end of the year the water column was isothermal.

\section{Phosphate}

Vertical distribution is shown in Fig. 2, and integral mean concentrations in Table I. The winter maximum found was $0.47 \mu \mathrm{g}$ atom P/1. on I5 February, and the lowest concentrations were $0.08-0.09 \mu \mathrm{g}$ atom $\mathrm{P} / 1$. at the 5 and $10 \mathrm{~m}$ levels in May and June. Phosphate remained low in the upper $20 \mathrm{~m}$ until September; the vertical distribution had become uniform by I5 October, and so remained until the end of the year. 


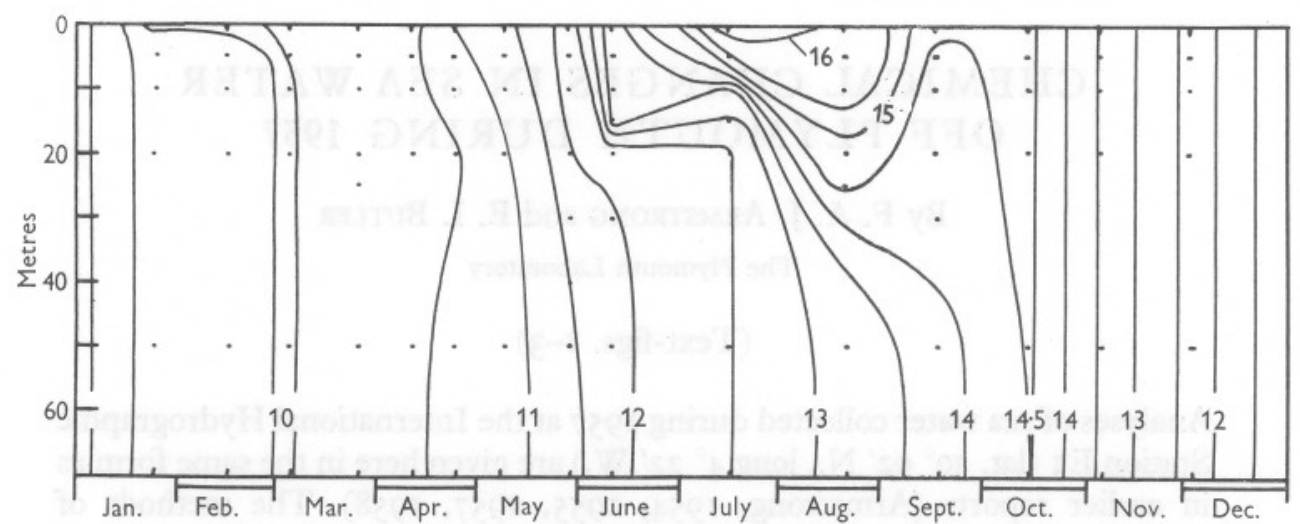

Fig. I. Vertical temperature distribution at International Hydrographic Station E I, 1957. Contour lines at $0.5^{\circ} \mathrm{C}$ intervals.

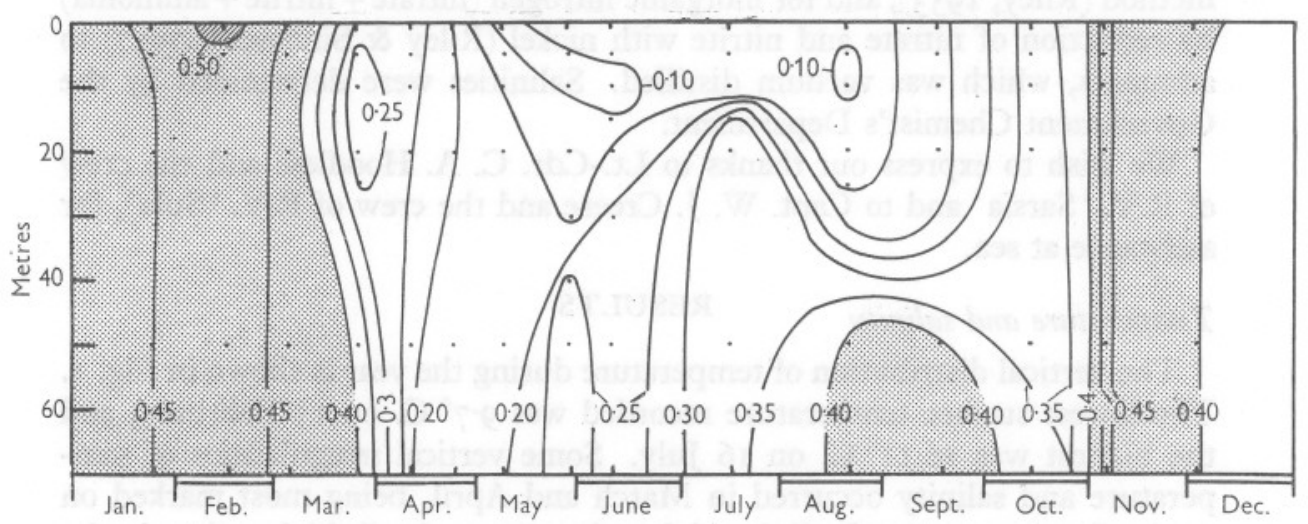

Fig. 2. Vertical distribution of phosphate at International Hydrographic Station E I, 1957. Contour lines at $0.05 \mu \mathrm{g}$ atom $\mathrm{P} / 1$. intervals.

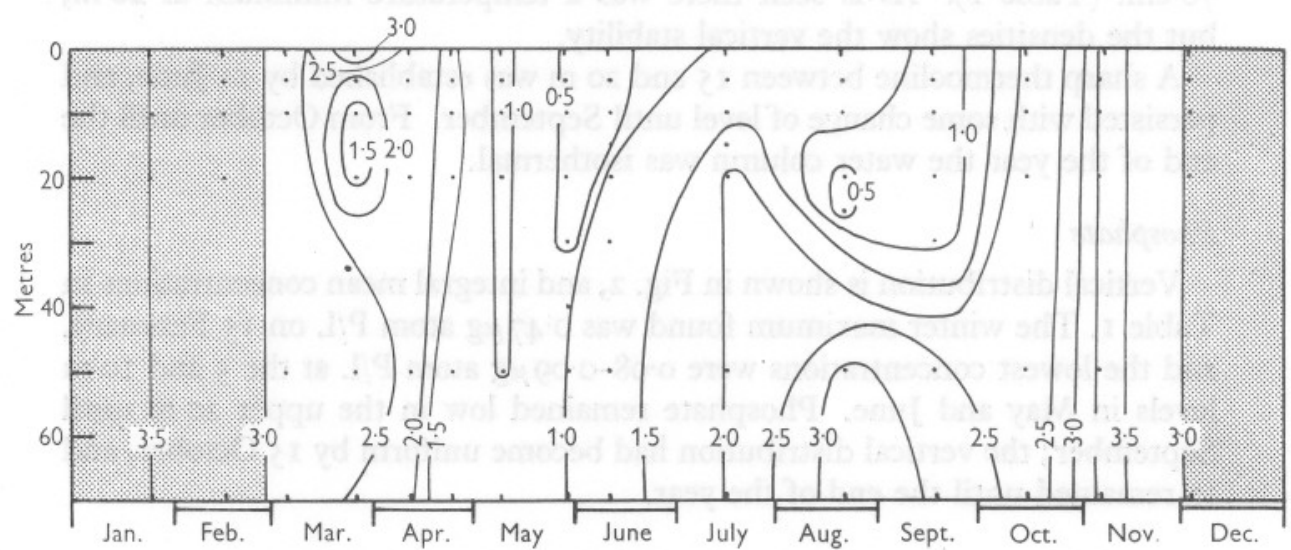

Fig. 3. Vertical distribution of silicate at International Hydrographic Station EI, 1957. Contour lines at $0.5 \mu \mathrm{g}$ atom $\mathrm{Si} / 1$. intervals. 


\section{'Total phosphorus'}

Determinations were made in January, February and March only, to find the winter maximum value. This was $0.63 \mu \mathrm{g}$ atom $\mathrm{P} / 1$. on 15 February.

\section{Silicate}

Vertical distribution is shown in Fig. 3, and integral mean concentrations in Table $\mathrm{I}$. The maximum found at the beginning of the year was $3.5 \mu \mathrm{g}$ atom $\mathrm{Si} / 1$. on 24 January. On the whole, higher silicon concentrations than usual were maintained during the year, as Table I shows. Values of less than $0.5 \mu \mathrm{g}$ atom Si/1. were found only on 29 May and II June, above the thermocline, and, surprisingly, at 20 and $25 \mathrm{~m}$ on 2I August. These low values came between considerably higher ones in the water above and below, as shown in Table 3.

TABLE 1. INTEGRAL MEAN CONCENTRATIONS IN WATER COLUMN AT STATION E1, 1957

\begin{tabular}{|c|c|c|c|c|c|}
\hline Date & $\begin{array}{l}\text { Phosphate } \\
(\mu \mathrm{g} \text { atom } \\
\mathrm{P} / 1 .)\end{array}$ & $\begin{array}{l}\text { 'Total-P' } \\
(\mu \mathrm{g} \text { atom } \\
\mathrm{P} / 1 .)\end{array}$ & $\begin{array}{l}\text { Silicate } \\
(\mu \mathrm{g} \text { atom } \\
\mathrm{Si} / 1 .)\end{array}$ & $\begin{array}{l}\text { Ammonia } \\
(\mu \mathrm{g} \text { atom } \\
\mathrm{N} / 1 .)\end{array}$ & $\begin{array}{c}\text { Inorganic } \mathrm{N} \\
(\mu \mathrm{g} \text { atom } \\
\mathrm{N} / 1 .)\end{array}$ \\
\hline 24 Jan. & 0.45 & 0.52 & 3.47 & 0.7 & 9.8 \\
\hline I5 Feb. & 0.47 & 0.63 & 3.35 & - & $9 \cdot 6$ \\
\hline 5 Mar. & 0.43 & 0.54 & $2 \cdot 71$ & - & - \\
\hline 26 Mar. & 0.31 & - & $2 \cdot 30$ & 0.7 & $I \cdot 7$ \\
\hline I I Apr. & 0.24 & 一 & $2 \cdot 25$ & - & - \\
\hline 24 Apr. & 0.21 & - & $\mathrm{I} \cdot 22$ & - & - \\
\hline 9 May & 0.16 & - & I.07 & - & - \\
\hline 29 May & 0.20 & - & 0.72 & $I \cdot I$ & $2 \cdot 6$ \\
\hline II June & 0.18 & - & 1.03 & 0.7 & $\mathrm{I} \cdot 6$ \\
\hline I6 July & 0.30 & - & $I \cdot 83$ & - & - \\
\hline 2I Aug. & 0.26 & - & $\mathrm{I} \cdot 87$ & - & - \\
\hline I7 Sept. & 0.31 & - & $\mathrm{I} \cdot 62$ & $\mathrm{I} \cdot 2$ & 6.9 \\
\hline Is Oct. & $0.3 \mathrm{I}$ & - & $2 \cdot 28$ & $\mathrm{I} \cdot 2$ & - \\
\hline 6 Nov. & 0.44 & - & 3.58 & - & - \\
\hline 3 Dec. & 0.42 & - & 3.07 & 0.4 & 3.7 \\
\hline
\end{tabular}

There was a significant fall in salinity in the upper Io $\mathrm{m}$ between July and August. This may show that water at this level has been replaced by other of different chemical properties, for although phosphate fell, silicate rose slightly, at the same time. There were also slight changes in the composition of the bottom water, but the change of salinity here may not be a significant one, and the changes in phosphate and silicate could be put down to a normal regeneration of these nutrients. The data are insufficient to explain the curious vertical distribution of silicate.

Layering of water masses at this station (apart from the annually developed thermocline) has been found from time to time in the past 8 years, having been revealed by irregularities in the silicate figures. Occasionally, laminar as well as bodily displacements of water must occur at $\mathrm{E}_{\mathrm{I}}$. 
TABLE 2. OBSERVATIONS AT STATION Eil, 24 APRIL 1957

\begin{tabular}{|c|c|c|c|c|c|}
\hline $\begin{array}{l}\text { Depth } \\
\text { (m) }\end{array}$ & $\begin{array}{c}\text { Temperature } \\
\left({ }^{\circ} \mathrm{C}\right)\end{array}$ & $\underset{(\%)}{\text { Salinity }}$ & $\begin{array}{l}\text { Density } \\
\text { in situ }\end{array}$ & $\begin{array}{l}\text { Phosphate } \\
\text { ( } \mu \mathrm{g} \text { atom } \\
\text { P/1.) }\end{array}$ & $\begin{array}{l}\text { Silicate } \\
\text { ( } \mu \text { g atom } \\
\mathrm{Si} / 1 .)\end{array}$ \\
\hline 0 & II $\cdot 0$ & $35 \cdot 19$ & $26 \cdot 94$ & 0.20 & I.5 \\
\hline 5 & I0. 88 & $35 \cdot 13$ & 26.91 & 0.19 & $I \cdot 5$ \\
\hline IO & 10.83 & $35 \cdot 14$ & $26 \cdot 93$ & 0.20 & I. 4 \\
\hline 20 & 10.45 & $35 \cdot 16$ & 27.01 & 0.21 & I. 8 \\
\hline 50 & 10.73 & $35 \cdot 29$ & 27.06 & 0.17 & 0.8 \\
\hline 70 & 10.65 & $35 \cdot 30$ & 27.09 & 0.25 & 0.8 \\
\hline
\end{tabular}

TABLE 3. OBSERVATIONS AT STATION E1, 16 JULY AND 21 AUGUST 1957

\begin{tabular}{ccc}
$\begin{array}{c}\text { Depth } \\
\text { (m) }\end{array}$ & \multicolumn{3}{c}{$\begin{array}{c}\text { Salinity } \\
(\%)\end{array}$} \\
$0 \cdot 5$ & $35 \cdot 13$ & Aug. \\
5 & $35 \cdot 16$ & $35 \cdot 12$ \\
I0 & $35 \cdot 17$ & $35 \cdot 10$ \\
15 & $35 \cdot 18$ & $35 \cdot 08$ \\
20 & $35 \cdot 20$ & $-15 \cdot 16$ \\
25 & - & $35 \cdot 16$ \\
50 & $35 \cdot 20$ & $35 \cdot 17$ \\
70 & $35 \cdot 21$ & $35 \cdot 18$
\end{tabular}

\begin{tabular}{cc}
\multicolumn{2}{c}{$\begin{array}{c}\text { Phosphate } \\
\text { July atom } \mathrm{P} / 1 .)\end{array}$} \\
0.11 & Aug. \\
0.15 & 0.11 \\
0.14 & 0.09 \\
0.36 & 0.10 \\
0.34 & 0.12 \\
0.33 & 0.14 \\
0.34 & 0.43 \\
\hline & 0.42
\end{tabular}

Silicate ( $\mu$ g atom $\mathrm{Si} / 1$.)

$\begin{array}{cc}\text { July } & \text { Aug. } \\ \mathrm{I} \cdot 2 & \mathrm{I} \cdot 6 \\ \mathrm{I} \cdot 3 & \mathrm{I} \cdot 4 \\ \mathrm{I} \cdot 3 & \mathrm{I} \cdot 4 \\ \mathrm{I} \cdot 7 & - \\ 2 \cdot 0 & 0 \cdot 2 \\ - & 0 \cdot 3 \\ 2 \cdot 0 & 3 \cdot 2 \\ 2 \cdot 0 & 3 \cdot 3\end{array}$

\section{Nitrogen}

Enough analyses to draw an isopleth could not be done, and integral mean values only are given here. The vertical distribution did, however, resemble that for phosphate. The values (Table I) in winter and summer resemble those obtained at E I by other methods in earlier years (Cooper, I933). The winter (maximum) ratio, $\mathrm{N} / \mathrm{P}=20 / \mathrm{I}$ by atoms or $9 \cdot 2 / \mathrm{I}$ by weight, was a little higher than the 16 or I7/I atomic ratio found in I93I by Cooper.

\section{Integral mean concentrations}

The spring decreases representing consumption of nutrients were: phosphate $0.29 \mu \mathrm{g}$ atom $\mathrm{P} / 1$., silicate $2.75 \mu \mathrm{g}$ atom $\mathrm{Si} / 1$., inorganic nitrogen $8.0 \mu \mathrm{g}$ atom N/1. The ratio N/P consumed was $27 \cdot 6 / 1 \mu \mathrm{g}$ atoms or $12 \cdot 4 / \mathrm{I}$ by weight and is rather higher than the mean ratio, I6.3/I, for a number of analyses of plankton from this area (Cooper, I937).

\section{SUMMARY}

The results of analysis of sea-water samples from the International Hydrographic Station E I during 1957 are given in graphical form and as integral mean values for the water column of $70 \mathrm{~m}$. The seasonal variation shows the consumption of nutrients during the spring growth of plants to have been: phosphate $0.29 \mu \mathrm{g}$ atom $\mathrm{P} / 1$., silicate $2 \cdot 75 \mu \mathrm{g}$ atom $\mathrm{Si} / 1$., inorganic nitrogen $8.0 \mu \mathrm{g}$ atom $\mathrm{N} / 1$. At the time of winter maximum the $\mathrm{N} / \mathrm{P}$ ratio was $20 / \mathrm{I}$ by 
atoms or $9 \cdot 2 / \mathrm{I}$ by weight. The ratio of these elements consumed was $27 \cdot 6 / \mathrm{I}$ by atoms or $12 \cdot 4 / \mathrm{I}$ by weight.

Unusual vertical distributions of silicate were found in April and August, and are attributed to laminar water movements.

\section{REFERENCES}

Armstrong, F. A. J., I954. Phosphorus and silicon in sea water off Plymouth during the years 1950 to I953. F. mar. biol. Ass. U.K., Vol. 33, pp. 381-92.

— 1955. Phosphorus and silicon in sea water off Plymouth during 1954. F. mar. biol. Ass. U.K., Vol. 34, pp. 223-28.

- 1957. Phosphorus and silicon in sea water off Plymouth during 1955. F. mar, biol. Ass. U.K., Vol. 36, pp. 317-r9.

— 1958. Phosphorus and silicon in sea water off Plymouth during 1956. F. mar. biol. Ass. U.K., Vol. 37, pp. 371-77.

COOPER, L. H. N., 1933. Chemical constituents of biological importance in the English Channel, November 1930 to January 1932. Part I. Phosphate, silicate, nitrate, nitrite, ammonia. F. mar. biol. Ass. U.K., Vol. I8, pp. 677-728.

- 1937. On the ratio of nitrogen to phosphorus in the sea. F. mar. biol. Ass. U.K., Vol. 22, pp. 177-82.

RILEY, J. P., 1953. The spectrophotometric determination of ammonia in natural waters, with particular reference to sea water. Anal. chim. acta, Vol. 9, pp. $575-89$.

Riley, J. P. \& Sinhaseni, P., I957. The determination of ammonia and total ionic inorganic nitrogen in sea water. F. mar. biol. Ass. U.K., Vol. 36, pp. I6I-68. 